\title{
5
}

\section{Blasphemy and sacrilege in the novel of magic realism: Grass, Bulgakov, and Rushdie}

\author{
Peter Arnds
}

Fortunately, at times in which the right to freedom of speech is threatened, there are artists who remind us of that right. In the face of those telling us that we ought to stand united behind our political leaders and who want to blacklist unpatriotic academics, in the face of these, we ought to brandish certain books. Books full of blasphemy and sacrilege reminding us that at times of political and religious monologism, we need to hear conflicting voices in order to preserve the spirit of liberalism. Mikhail Bakhtin's theory of heteroglossia still enforces this message. According to the Russian critic, in the comic modern novel, heteroglossia is 'parodic and aimed sharply and polemically at the official languages of its given time'. ${ }^{1}$ Bakhtin challenges the tyranny of unitary languages of regimes founded on religious, national, cultural, racial, or even linguistic monologues. What are some of these liberal, liberating books that make the principle of heteroglossia their own in order to subvert political and religious monologism? To demonstrate how blasphemy and sacrilege are used to attack secular and religious ideologies, this article will take a closer look at three world-renowned authors and their texts: Grass's The Tin Drum, Bulgakov's The Master and Margarita, and Salman Rushdie's Midnight's Children.

\section{Grass}

John Irving once called Grass's The Tin Drum the greatest novel by a living author. To this day, Grass's book remains one of the most important works of literature for the construction of postwar German identity. As a writer, Grass traditionally sides with the oppressed, with society's marginalised figures. His novel is, among other things, a literary treatment of the Nazi ideology of race and eugenics, resulting in the persecution of asocials as 'life unworthy of life', their extermination in psychiatric institutions in the Third Reich, and their marginalisation in the Adenauer period. Grass's Tin Drum is the story of Oskar Matzerath who refuses to grow up during the Nazi regime. Oskar literally stops growing at the age of three and through his child-like actions of drumming and screaming glass to pieces, protests against the adult world that surrounds him. 
After the war, he transforms from a child who does not want to grow into a grotesquely deformed dwarf, whose hump is symbolic of Germany's ugliness, of the burden of history that Germany carries upon its shoulders. The Tin Drum reflects all those paradigms of the carnival with its potential of blasphemy and sacrilege that Bakhtin outlines in his monumental study Rabelais and his World. All three authors, Grass, Rabelais, and Bakhtin, react through their works to the oppressive regimes of their times, the rule of Charles V in Rabelais, Stalinist Russia in Bakhtin, and the Third Reich in Grass. For Rabelais, Bakhtin, and Grass, the spirit of carnival with its emphasis on the grotesque signifies the symbolic destruction of authority and official culture and the assertion of popular renewal. A fascinating parallel between Bakhtin and Grass, one that makes it impossible to read The Tin Drum without thinking of the Russian critic, is that both writers critique the official discourse of a regime that appropriates folk culture for its oppressive politics and for rejecting and killing undesirable individuals. While Bakhtin uses theory, the theory of blasphemy to attack Stalinism, Grass attacks German conservatism more directly through fiction. While for obvious reasons, the more muted criticism of Stalinism by people like Bakhtin and the Russian novelist Mikhail Bulgakov was levelled entirely at the State, Grass's most blasphemous scenes are levelled against the Church in Germany, specifically against its silence during the Nazi period.

The difference between aboriginal peoples and pagan societies, which manage to wed the forces of chaos with the forces of order, and Christianity, which started separating these two principles by distinguishing between Jesus and Satan, becomes interesting within the context of Grass's novel, which reflects this pagan union of the Apollonian and Dionysian sphere. It does this by merging in Oskar Matzerath the figures of Jesus and Satan, of victim and fascist. Oskar can never be just one: the dividing line of any dialectic is blurred in this book and, like all archetypal tricksters, Oskar finds himself on the threshold between two domains. The trickster's typical location in European culture is the marketplace, and as Bakhtin tells us in the Middle Ages and the Renaissance, this was the place in which curses, profanities, and oaths reigned. ${ }^{2}$ While the sacred was reserved for the church, the profane reigned outside of church, primarily in the marketplace. Pro-fanum translates into 'before the temple'. In early modern European culture, the grotesque became most visible in the marketplace, a place not only of multicultural interaction but also a venue for all sorts of groups that later became increasingly segregated from society: gypsies, transient musicians, exotics of doubtful origin, freed slaves, midgets and giants. ${ }^{3}$ Yet with the formation of the bourgeois class, socially inferior classes in marketplaces and fairs increasingly became the 'object of the respectable gaze' 4 by which the bourgeois class was able to confirm its own superiority. Particularly, the slave from the colonies, the dwarf, and the pig were displayed and celebrated at the fair because of their low status. Alongside with their 
segregation within the forming nation-state, slaves and dwarves then became increasingly banished from church. ${ }^{5}$ Oskar's presence in church is in itself a violation of the sacred realm through the profanity of his grotesque body and all his body stands for, as opposed to one of his counter images, the classical body of the athlete on the cross, who is flexing his muscles and expanding his chest over the main altar of the Danzig Sacred Heart Church. In addition, Oskar repeatedly violates this physical division between the sacred and the profane by taking profane language and actions into church. As a culture of shame and guilt, Germany in the 1950s had its areas of silence - the Nazi crimes, the Holocaust and euthanasia. A central moment of breaking this silence about the Holocaust, in which Oskar accuses the church, that sacred domain opposed to the grotesque, of its passivity in the face of Nazi atrocities, occurs when he gives the Jesus figure his drum and tells him to use it, as a way of protesting against what is happening on the political stage at the same time. This is a double disruption of the sacred, both in the sense that Germans in the 1950s did not want to hear about the Holocaust and the war, and in locality, the desecration of the sacred ground.

The Catholic Church in particular is the target of Grass's satire. As Günter Lewy has shown, the Catholic Church silently supported the Final Solution, while it followed the general public in its outcry against the practice of euthanasia. ${ }^{6}$ The main reason for the Catholic Church's protest against euthanasia was that here Germans were killed while the Final Solution targeted the Jews, who had killed Jesus Christ. ${ }^{7}$ In 1939, Archbishop Gröber argued that because the Jews had killed God, Christianity was not to be regarded as a product of the Jews but was 'in the most intimate union with the Germanic spirit' ${ }^{8}$ This appropriation by the German church of Jesus into its own ranks is reflected in Grass's Aryanisation of the Jesus figure à la Leni Riefenstahl. Grass's church scenes exhibit some of the most offensive passages in the book by conflating sacred images with what Bakhtin calls the material bodily lower stratum, as Catholicism never ceases to inspire Oskar with blasphemy. In picaresque fashion, Oskar mutters commentaries on the Mass while moving his bowels, he equates Jesus with his philandering father Jan Bronski, he touches the little Jesus figure's penis, his watering can, as he calls it, thus giving himself a massive erection, and he sits on the Virgin Mary's thigh. In the marketplace, Bakhtin argues, 'the most improper and sinful oaths were those invoking the body of the Lord and its various parts, and these were precisely the oaths most frequently used'. ${ }^{9}$ Oskar's drumming, and especially the drumsticks, belong to a series of phallic symbols. Being dactyls like the Tom Thumb figure himself that Oskar is partly modelled on, these are grotesque images of potency that contrast starkly with Jesus's own flaccid penis as a symbol of the church's political impotence. These carnivalesque images subvert the authority of the church, conflating the theme of the Holocaust with folk humour. 
Oskar's blasphemies turn into crime when he steals nativity figures from numerous churches. In these later church scenes, Oskar uncrowns the church Jesus by adopting his name as the leader of a street gang and by sawing him off along with the other two figures, John the Baptist and the Virgin Mary. He has his 'disciples', the gangsters named the Dusters, perform Catholic rituals such as genuflections by the holy-water font or enact an impromptu Mass and invoke the ite missa sunt, a line that was also the object of derision in the medieval Feast of Fools, where it was converted into the threefold braying of an ass performed by the priest. ${ }^{10}$ We can see to what extent Grass's book from 1959 is steeped in these early cultural traditions of Europe. In synchrony with other tricksters who muddy high gods and 'are made in and for a world of imperfections', in which they 'do not wish away or deny what seems low, dirty, and imperfect', 11 Oskar's blasphemies in church challenge religious idealism and indict the church's silence towards the Nazis' practice of euthanasia, of the killing of the physically and mentally degenerate, of doing away with what seemed to them low, dirty, and imperfect. This union between the church and the totalitarian state is explicitly addressed in Grass's equation of the classical body of Jesus and the perfect Aryan body, the athletes of the 1936 Olympics and Jesus's blue eyes, and the equation of the holy cross and the swastika. Oskar questions Jesus as a culture-hero and concludes that he, Oskar, is a more genuine Jesus than the other, for at least Oskar drums resistance to the Nazis with his tin drum. His actions seem to imply the question: Where was God during the Holocaust? Where were Jesus's miracles then? Moreover, Oskar's second form of protest, his desire to scream glass to pieces in church, could be read as a form of protest against the broken glass during Reich Crystal Night and the church's silence.

\section{Bulgakov}

Grass's book is part of a tightly woven fabric of texts that are steeped in the tradition of the Menippean satire. The revival of this genre in the twentieth century, whether in Russia or Germany, has the function of social criticism. It is subversive, blasphemous and sacrilegious literature that forms a carnivalesque counter-culture to the seriousness of any officialdom. Bakhtin wrote his book on Rabelais with this intention and he did for literary theory what Mikhail Bulgakov's The Master and Margarita did in fiction. The publication of both books was delayed for many years due to the censorship under Stalinism. Bakhtin's dissertation on which his book is based was not completed until 1940, he did not receive his degree until 1951, and the book was not published until 1965. Bulgakov's novel experienced a similar publication history: it was started in 1928 but was not published until 1966, 26 years after his death, as a censored version in a Moscow journal. Mikhail Bulgakov's The Master and Margarita is a novel of grotesque, fantastic realism written during the dark era of the Stalinist purges, a novel about the evils of Stalin's Russia and, as such, a monument to 
the indestructibility of art much like Grass's novel, which also revives what the Nazis had tried to eradicate as degenerate. Bulgakov's satire, too, lends itself to a Bakhtinian interpretation with its concept of the carnival as a temporary liberation from the prevailing truth and from the established order. Like Grass's novel, The Master and Margarita was itself influenced by Rabelais. Bulgakov's novel is about the fate of a novel about Pontius Pilate and Jesus Christ, written by the protagonist, the Master. It blends a retelling of Christ's ascent to Golgotha and his execution with the incredible events surrounding a visit by Woland, Satan, the central trickster figure in this text, and his minions, to the Moscow of Stalinism. The presence of Jesus, Ieshua, as a character of a novel was unthinkable for the atheist Stalinist era. This is very different from Grass's kind of blasphemy, a blasphemy within and directed against the Church. Bulgakov's novel abounds if not in blasphemy then in a sort of secular sacrilege targeted at the state and the absence of any church. In the two central figures, the Master and Pontius Pilate, we obtain the two positions of the persecuted artist and the tyrant. The Master is to an extent a self-portrait of Bulgakov and his difficulties as a writer under Stalin. Stalin can be discerned both in the figure of Pontius Pilate, who condemns innocent people to death, and Woland, the Devil. The novel shares with Grass's The Tin Drum the installation of a vagrant Jesus figure, who in both cases has to carry the burden imposed upon him by the crimes of a totalitarian regime, its cowardice, betrayals, and murders. That Oskar Matzerath increasingly identifies with Jesus at the end of Grass's novel indicates that he is the victim of the crimes of humanity par excellence and, like Bulgakov, Grass intends to remind us that the story of Jesus continues to have metaphorical relevance for our own day, that there will always be a Pontius Pilate who ends up crucifying a Jesus.

Bulgakov's novel can quite literally be characterised as a work of magic realism. It engages in mock uncrownings of officially respected figures from the world of literature and theatre and makes fun of the mysterious disappearance of Moscow inhabitants, a common phenomenon under Stalinism. The unreality of the totalitarian regime, which Hannah Arendt has described as a 'superior realism' surrounding these regimes, may be the reason why some artists respond to these times with works of magic realism. ${ }^{12}$ Mikhail Bulgakov, for fear of retribution, never talks openly about Stalinism but refers to it as witchcraft: 'And it was two years ago that inexplicable things began happening...people started disappearing without a trace. Once, on a day off, a policeman appeared, summoned the second lodger (whose name has been lost) into the front hall, and said that he had been asked to come down to the police station for a minute in order to sign something. The lodger told Anfisa...he would be back in ten minutes... Not only did he not return in ten minutes, he never returned at all...it was witchcraft pure and simple, and ... as everyone knows, once witchcraft gets started, there is no stopping $\mathrm{it}^{\prime} .{ }^{13}$ One of the most famous lines from this novel 
- 'once witchcraft is started, there is no stopping it' - expresses totalitarianism's self-consuming racism, the never-ending process of having to find enemies. It is passages like this one that mark moments in the text where, due to the conflation of reality with surrealism, the term 'magic realism' becomes justified in the highest degree. Evidently, at times of extreme censorship only metaphorical language can save the artist from persecution; hence the magic realist novel can be a tool to express and attack the politics of totalitarian regimes. What this novel describes as witchcraft and fantasy, was, however, a grim reality that had nothing to do with magic. The novel displays a rediscovery of the iconography of Hell, which had gone missing in the bourgeois age, that joyful hell, of which Bakhtin speaks, to be found in medieval carnival and in Rabelais. Griboedov House, for example, the primary hangout for the Muscovite literary world and for Woland and his devils is such a hell. Particularly its famous restaurant, in which Woland gives his satanic ball, with its incredibly loud jazz band and the laughter that roars through its vaults is the main carnival locus which parades beauty and ugliness, life and death, and is reminiscent of Grass's restaurant, the Onion Cellar and its own jazz band. In Grass's Onion Cellar, Germans are taught to mourn by crying over onions. In both novels jazz has a liberating function from oppression. In The Tin Drum, Oskar disperses a Nazi party rally from inside a rostrum by drumming to the rhythm of a Charleston, 'Jimmy the Tiger', which has the power to dissolve the uniformity of the saluting Volkskörper, the folk body. In accordance with Cornel West's thoughts in his recent book Democracy Matters on the potential of jazz and blues to resist the stifling of democracy and to give tragicomic hope in the face of racism, Oskar's music temporarily dissolves the rigidity of the Sieg-Heil salute, a central symbol of the Nazi race ideology. Similarly, the jazz in Bulgakov's Griboedov House can be read as a carnivalesque form of resistance to the Puritanism of Stalinism.

Like The Tin Drum, The Master and Margarita parodies God, installs Satan as a central figure, is intertextual with Goethe (Faust in Bulgakov, the Goethean Bildungsroman in Grass), conflates the rational with the irrational, pits irrational elements against the rationalist party monologue, cosmopolitanism with nationalism. Bulgakov's devil Woland, for example, is described as a polyglot foreigner. In both novels, the idea of cosmopolitanism clashes with the politics of rootedness. Primarily, however, Bulgakov's novel fulfils what Bakhtin saw in Dostoevsky's novels, their polyphony, heteroglossia, a never-ending dialogue in opposition to the monologism of Stalinism, a novel that is open-ended, unfinalised. In a key moment, in the Master's novel within the novel, he has Yeshua save Pilate from eternal damnation, thus guaranteeing the persistence of a dialogue between irrationalism in the form of faith (Jesus) and reason (Pilate, Stalin). This union between rationalism and irrationalism also comes about in The Tin Drum, where Oskar advocates a union between the Apollonian and the Dionysian principles borrowed from Nietzsche's Birth of Tragedy. It seems that 
these two European novels finally attempt to achieve to mend the central split that goes through the cultural history of modernity, that split between reason and unreason that emerges from the Enlightenment.

\section{Rushdie}

While Grass writes against the political abuse of folk culture in Nazi Germany, Bulgakov writes against the suppression of the Christian myth following the Communist revolution. In both books, myth is disentangled from the grasp of ideological abuse. This also happens in Rushdie's books, both in Midnight's Children and Satanic Verses. As Grass's The Tin Drum draws on previous texts, it becomes the palimpsest for later texts. Salman Rushdie openly admitted to having been influenced by Grass. ${ }^{14}$ The parallels between these two authors are legion. While Grass juxtaposes Germans and Poles, one of Rushdie's central themes is the relationship between Muslims and Hindus. The works of both writers display a high degree of intertextuality and heterogeneity and both have provoked strong reactions from the people who do not agree with their use of blasphemy and sacrilege, although arguably conservative reactions to Grass's The Tin Drum in places like Bavaria in the early 1960s and Oklahoma in the mid-1990s fade in comparison with the fatwa which Khomeini placed on Rushdie after the publication of The Satanic Verses in 1989. One of the most interesting connections between The Tin Drum and Midnight's Children is their fantastic realism, their revival of the picaresque tradition. Most of Rushdie's characters display the kind of homelessness of which Bakhtin speaks, the dubious origin of the picaro, that great blasphemer in world literature. We realise to what extent the picaro himself stems from an intercultural archetype that transcends Europe, the mythological trickster, whose central function is to criticise society from its margins. As tricksters, Oskar Matzerath and Saleem Sinai, the hero of Midnight's Children, have in common that they are equipped with magic weapons allowing them to commit deeds of blasphemy and sacrilege. What is Oskar's scream, by which he destroys the glass in churches, is Saleem's extremely sensitive nose that allows him to smell the thoughts of people. As tricksters, they are marginalised, figures on the threshold, and find themselves in what the anthropologist Victor Turner has called a zone of liminality. ${ }^{15}$ It is precisely from their liminal position that they are able to levy acts of blasphemy criticising official ideologies, the times in which they live. Both stand on the threshold between two historical ages, Nazism and post-war Germany on the one hand, India as a British colony and postcolonial India on the other. Both texts revolve around the Stunde Null, the zero hour of the nation state, 1945 in Germany and 1947, the day of Indian Independence. 1945 marks the date when Oskar is transformed into a grotesquely misshapen dwarf, while precisely at the stroke of midnight preceding Indian independence, Rushdie's protagonist Saleem Sinai is born together with the other thousand midnight children. What moves these 
two novels into close proximity is the grotesque body of the protagonist and their grotesque, sacrilegious representation of history. While Oskar's hump is a symbol of German guilt that he carries on his shoulders and while his deformity also reflects the ugliness of Germany after 1945, Saleem Sinai, whose physiognomy resembles that of the Hindu Elephant God Ganesha, carries the very shape of the Indian subcontinent in his face, as his teacher Zagallo points out with his Peruvian accent:

'Sons of baboons! Thees object here' — a tug on my nose — 'thees is human geography!' 'How sir where sir what sir?' Zagallo is laughing now. 'You don't see?' he guffaws. 'In the face of thees ugly ape you don't see the whole map of India?' 'Yes sir no sir you show us sir!' 'See here - the Decan peninsula hanging down!' Again ouchmynose. 'Sir sir if that's the map of India what are the stains sir?' It is Glandy Keith Colaco feeling bold. Sniggers, titters from my fellows. And Zagallo, taking the question in his stride: 'These stains,' he cries, 'are Pakistan! Thees birthmark on the right ear is the East Wing; and thees horrible stained left cheek, the West! Remember, stupid boys: Pakistan ees a stain on the face of India!' 'Ho ho,' the class laughs, 'Absolute master joke, sir!' But now my nose has had enough; staging its own, unprompted revolt against the grasping thumb-and-forefinger, it unleashes a weapon of its own...a large blob of shining goo emerges from the left nostril, to plop into $\mathrm{Mr}$ Zagallo's palm. Fat Perce Fishwala yells, 'Lookit that, sir! The drip from his nose, sir! Is that supposed to be Ceylon?'16

The text abounds in 'images of the grotesque body draining into the world' which serve 'a Menippean vision of renewal and progress' that is 'referentially directed towards the qualities of Indian society that Rushdie valorises: pluralism, democracy, hybridity, and change' and they satirically attack the 'forces in modern India and Pakistan that deny those principles: fundamentalism, despotism, purity, and stasis' ${ }^{17}$

The representation of history in Midnight's Children is steeped as much in folk culture as that of The Tin Drum. In a conversation that Grass and Rushdie had in the mid-1980s, they both admitted to each other that their use of the fantastic and of the fairy-tale world stems from their cultures' individual literary heritage. While Rushdie emphasises the importance of the Arabian Nights for his novel, of the stories of $A$ Thousand and One Nights, Grass's literature is deeply rooted in the German Baroque and Romantic tradition, the picaresque novel and the fairy tales. Like Grass, who destabilises the mendacity of post-fascist rationalism, Rushdie attempts to subvert the official view of Indian history as a success story, as what Nietzsche called 'monumental history', the history of India's great leaders. ${ }^{18}$ Against this monumental vision of India's history, Rushdie offers his critical view of history. The story of Saleem Sinai is the story 
of India's common people. Like Grass, Rushdie thus reinstalls 'low' culture over 'high' culture, elevates the marginalised over those at the centres of power. The subversion of an official discourse is, in both cases, achieved specifically through the sacrilegious conflation of important historical events with the banality of the protagonist's private life and through a revival of myth and irrationalism suppressed by both new states, both under Adenauer's politics of rationalism and Nehru's secularisation. In order to show how ludicrous the concept of the Stunde Null, the zero hour, this sort of tabula rasa made of Nazism or colonialism, really is, Rushdie recycles a central scene from Grass, the Onion Cellar episode, which resurfaces as Mumbai's 'Midnite Confidential Club'. Both authors want to bring back the past and understand that nothing will disappear, everything will come back. What is catharsis through onions in Grass corresponds to Rushdie's chutney, the sweetsour 'chutney of memory'.

Preserving the past is a concern in all three books. Rushdie's image of the pickling factory that Saleem works in is a fitting motif for this chutneyfication of history and the narrator compares his thirty chapters with pickle jars in which the past is preserved. Grass, Bulgakov, and Rushdie engage in myth in order to preserve the past and a cultural heritage that the great rulers of their countries threaten either to manipulate or to suppress. Grass offers his vision of myth and folk culture in opposition to the Nazis' ideological manipulation of myth and folk culture and the spirit of rationalism under Adenauer. By way of parody, Bulgakov reinstalls central icons of the Christian myth in opposition to Stalin's imposed atheism. Rushdie writes in opposition to Jawaharlal Nehru and his daughter Indira Gandhi's suppression of Hindu and Muslim traditionalism for the sake of their monumental vision of history that focuses on the great leaders but not on the people. In Midnight's Children, he revives Hindu myth, for example, in the character of the Widow who drains all hope from the 1001 children born at the stroke of midnight of 15 August 1947, the day of Indian Independence from colonial rule. This figure can serve as a pars pro toto to demonstrate that this novel is a work of magic realism, for, at a realistic level, the Widow symbolises Indira Gandhi and her rule of terror during the Emergency period (1975-77), while at the level of myth, she is made to resemble the evil goddess Kali, who is often represented 'with protruding tongue, garland of skulls, and hands holding weapons and severed heads, stark naked upon the prostrate body of her beloved consort Shiva' ${ }^{19}$

This revival of Hinduism becomes even more problematic in The Satanic Verses where, in truly satirical manner, elements are shamelessly mixed, in this case the blasphemous mixing of religious icons. When the Muslim Gibreel, one of the two central characters, enters the film world, one of his first roles is to play the Hindu god Ganesha, with elephant trunk and large ears. Later, he metamorphises into Hanuman, the monkey king from the epic Ramayana. Rushdie's deconstruction of the dictatorial politics of the Indian film industry 
reminds us of Grass's and Bulgakov's parody of monological prose like the Bildungsroman of German Classicism and Socialist Realism, but among the greatest offences is Rushdie's mixing Islam with Hinduism.

In conclusion, one could argue that the literature of magic realism attacks primarily the official discourses of the church and the state. In this satirical literature, which is steeped in earlier European traditions such as the menippean satire or the picaresque novel, blasphemy and sacrilege, the rupturing of the sacred realm (church and state) through the profane (pro-fanum), are levelled against the Church's and the State's mechanisms of oppression. If we believe with Horkheimer and Adorno in the dialectic of Enlightenment, this implies that reason can become oppressive, that rationalism can reach a point at which it perverts into irrationalism, which no doubt it did under totalitarian rule. In the fiction of magic realism, Western rationalism becomes the target of satirical representations of irrationalism. What Deleuze and Guattari have, in their book Mille Plateaux, called the arborescence of Western societies, the deep roots of their teleologies and their territorialism, is being subverted through what they call the rhizome, the shallow roots associated with deterritorialisation, nomadism, and homelessness, for which tricksters, picaros, and other literary nomads are literary representations. In this body of literature, the official world is always being subverted through modes of the rhizome. We encounter these two realms, Deleuze's arborescence versus rhizomatics, in authors like Grass, Irving, Rushdie, Tournier, Garcia Marquez, but also in Bruce Chatwin's Songlines, to add an example from Australia, where the rhizomatic world of the indigenous peoples clashes with Western racism and its arborescence. As jazz and blues are part of the rhizomatic world giving tragicomic hope to African Americans so are the songlines, that intricate web of dreaming paths as the manifestation of an ancient nomadic culture. The trickster and the picaro are the great wanderers and blasphemers of the mythological and fictional world challenging the Gods, the rulers, and the sedentary bourgeois who hold still in the face of misrule. A question that remains is: Who will write the great heteroglot novel that parodies the Bush era and America's foreign policy? To date it has not yet been produced.

\section{Endnotes}

\footnotetext{
1 Mikhail Bakhtin, 1981, The Dialogic Imagination: Four Essays by M. M. Bakhtin, Caryl Emerson, Michael Holquist (eds.), Austin: University of Texas Press, p. 668.

2 Mockery, abuse, and embarrassment in the marketplace seem to be a European phenomena. By comparison, in Native American cultures like that of the Hopi, laughter itself is often sacred and lacks cynical undertones, a fact which is confirmed by their rituals in the plaza, the centre of the pueblo. Here rituals in which clowns allude to the sexual act and the process of defecation are performed without embarrassment and accompanied by laughter that contains no derision. See Richard Erdoes and Alfonso Ortiz 1998, American Indian Trickster Tales, London: Penguin, p. xxi.

3 Peter Stallybrass and Allon White, 1986, The Politics and Poetics of Transgression, Ithaca: Cornell

University Press, p. 36.

4 Stallybrass and White, p. 42.

5 Jack Zipes (ed.), 1987, The Complete Fairy Tales of the Brothers Grimm, New York: Bantam, p. 659.
} 
6 Günter Lewy, 2000, (1964), Nazi Germany and the Catholic Church, New York: Da Capo Press, p. 292. 7 Ibid., p. 279, for example: 'the veteran National Socialist priest Father Senn...in 1934 hailed Hitler as the tool of God, called upon to overcome Judaism'.

8 Ibid., p. 279.

9 Mikhail Bakhtin, 1984, Rabelais and his World, Bloomington: Indiana University Press, pp. 192-93.

10 Jung quoted in Paul Radin, 1972, The Trickster: A Study in American Indian Mythology, New York: Schocken Books, p. 198.

11 Lewis Hyde, 1998, Trickster Makes this World, New York: North Point Press, p. 90.

12 Hannah Arendt, 1973, The Origins of Totalitarianism, New York: Harcourt Brace \& Company, p. 353.

13 Mikhail Bulgakov, 1996, The Master and Margarita, New York: Random House, p. 63.

14 For example, the work of Patricia Merivale, 1990, 'Saleem Fathered by Oskar: Intertextual Strategies in 'Midnight's Children' and 'The Tin Drum', Ariel: A Review of International English Literature, vol. 21, no. 3, pp. 5-21; Rudolf Bader, 1984, 'Indian Tin Drum', The International Fiction Review, vol. 11, no. 2, pp. 75-83; and E. W. Herd, 1989, ‘Tin Drum and Snake-Charmer's Flute: Salman Rushdie's Debt to Günter Grass', New Comparison, vol. 6, pp. 205-18.

15 K.M. Ashley, 1990, Victor Turner and the Construction of Cultural Criticism, Bloomington: Indiana University Press, p. xviii.

16 Salman Rushdie, 1980, Midnight's Children, New York: Knopf, p. 294.

17 John Clement Ball, 1998, 'Pessoptimism: Satire and the Menippean Grotesque in Rushdie's Midnight's Children', English Studies in Canada, vol. 24, no. 1, pp. 61-81, at 73-4.

18 David Price, 1994, 'Salman Rushdie's Use and Abuse of History in Midnight's Children', Ariel: A Review of International English Literature, vol. 25, no. 2, pp. 91-107, at 96-106.

19 Ibid., p. 98. 